УДК 619:591.27

(C) 2015

Киричко Б. П., доктор ветеринарних наук,

Звенігородська Т. В., кандидат ветеринарних наук, Семіренко В. В., аспірант

(науковий керівник - доктор ветеринарних наук Б. П. Киричко)

Полтавська державна аграрна академія

\title{
КЛІНІЧНА ТА РЕНТГЕНОЛОГІЧНА ХАРАКТЕРИСТИКА ЗАПАЛЬНО-ГНІЙНИХ ПРОЦЕСІВ ДИСТАЛЬНОГО ВІДДІЛУ КІНЦІВОК У СВИНЕЙ
}

\section{Рецензент - доктор ветеринарних наук П. І. Локес}

У наведених матеріалах наукового дослідження висвітлені клінічні ц̌ рентгенологічні особливості перебігу запально-гнійних процесів дистального відділу кінцівок у свиней з метою вдосконалення діагностичної та диференційно-діагностичної бази. Загальними й спеціальними методами клінічного дослідження встановлено ознаки генералізованого гнійного остеомієліту, артриту, параартикулярної флегмони з ураженням копитцевої $i$ вінцевої кісток, а також відповідних суглобів.

Ключові слова: свині, кінцівки, гнійнонекротичні прочеси, клінічні дослідження, рентгенографія, флегмона, остеомісліт.

Постановка проблеми. У структурі захворювань свиней, особливо в окремих господарствах промислового типу, значний відсоток займають хвороби опорно-рухового апарату $[1,4,7,8]$.

Хвороби кінцівок, зазвичай, супроводжуються больовою реакцією, дезадаптацією, втратою здатності конкурувати за місце біля годівниці. Це призводить до втрати живої маси, зниження продуктивності, запліднюючої здатності і в кінцевому результаті - до вибракування. Більшість авторів основною причиною виникнення патології кінцівок у свиней називають утримування їх на щілинних залізобетонних підлогах, де тварини часто травмуються. В результаті розвивається кульгавість, а в разі мікробної інвазії - розвиваються запальні та гнійно-запальні процеси усього дистального відділу кінцівок. У таких випадках вибраковування поголів'я може досягати 20-26 \% [1-5, 8].

Аналіз основних досліджень і публікацій, у яких започатковано розв'язання проблеми. Численні наукові дослідження підтверджують залежність поширення хвороб кінцівок та умов утримання тварин [1-7]. Але, на жаль, хвороби кінцівок у свиней являють собою малодосліджену ділянку ветеринарної медицини, в якій кількість точних спостережень досить незначна, а експериментальні дослідження майже відсутні $[3,4]$.
Мета дослідження - вдосконалення діагностичної і диференційно-діагностичної бази.

Завдання - дослідження клініко-рентгенологічної характеристики гнійно-некротичних процесів дистального відділу кінцівок у свиней.

Матеріали і методи досліджень. Об'єктом дослідження були гнійно-запальні процеси дистального відділу кінцівок свиней. Досліджували хворих свиней порід велика біла та ландрас. Використовували набір загальних та спеціальних методів місцевого клінічного дослідження (огляд, пальпація, рентгенографія). Рентгенографію виконували апаратом «Арман» 9л5 з використанням рентгенівської плівки «Kodak» за жорсткості 50 кВ та експозиції 4 мА/с у двох взаємно перпендикулярних проекціях - прямій і боковій.

Результати досліджень. Загальними методами клінічного дослідження об'єктивно встановлено набряк і пастоподібність тканин проксимальніше вінчика, за пальпації - гостра локальна болючість і підвищена місцева температура. Місцями реєстрували флюктуацію та інші ознаки гнійного розплавлення. Патологічний процес ускладнювався появою декількох гнійних вогнищ, нориць, висипами на шкірі, відшаруванням рогової кайми. На рентгенограмах визначали збільшення об’єму м'яких тканин. У результаті набряку підшкірної жирової клітковини зникає чіткість контурів між нею і нижче розташованими анатомічними шарами, знижується їх прозорість. На усіх проаналізованих рентгенограмах реєстрували ураження дистальної та середньої фаланг пальців, розширення їх суглобових поверхонь, розмитий малюнок кісткових трабекул.

Переважно вогнища деструкції кісткової тканини локалізувалися в товщі кортикального шару. Вони множинні, дрібні, з нечіткими контурами, створюють картину плямистих просвітлень. Кортикальний шар нерівномірно стоншений. Деструкція кісткової тканини не $\epsilon$ ранньою, але найбільш явною ознакою остеомієліту. 

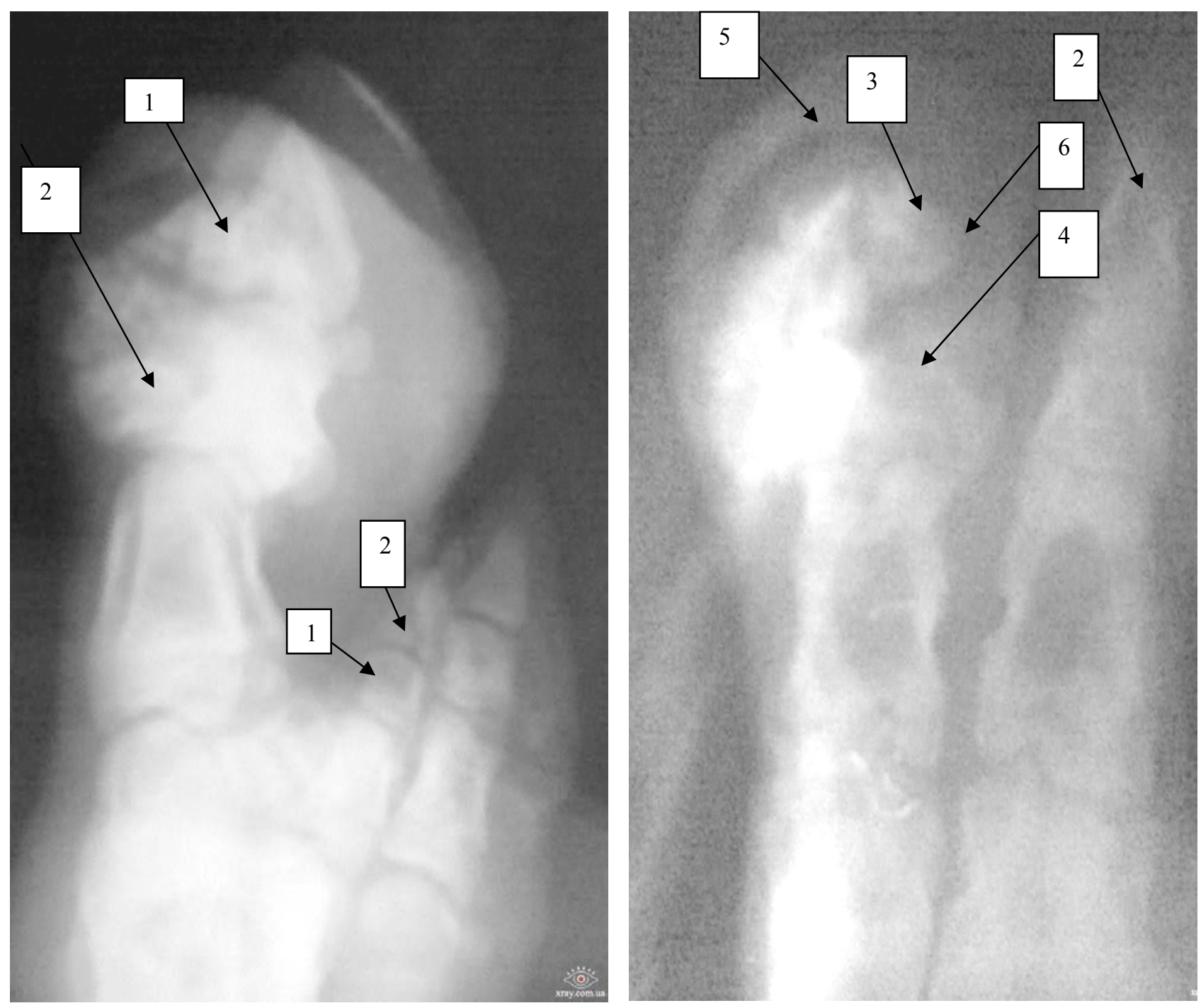

Рис. 1. Рентгенограма дистального відділу кінцівки у свині (пряма і бокова проекції):

1, 2 - потовщення середньої (вінцева кістка) та дистальної (копитщева кістка) фаланг з наявністю патологічного кісткоутворення з хаотичною структурою та відносно чіткою контурачією;

3, 4-розширення й узурачія суглобових поверхонь середньої та дистальної фаланг; 5 - ознаки наявності газу у вигляді затемненої смуги; 6 - набряк тканин.

В основі гнійного запалення кістки лежать процеси деструкції в кістковій тканині. Гнійна хірургічна інфекція призводить до розсмоктування та розплавлення кісткових елементів. Однак реактивні та репаративні зміни також відіграють свою роль. Таким чином, разом 3 руйнуванням кісткової тканини, відмічали і значне ії творення, що виявлялося у патологічному збільшенні об'єму кісткової тканини, потовщенні фаланг пальців. Суглобові поверхні розширені, визначаються поодинокі щілини, через які виділяються

\section{БІБЛІОГРАФІЯ}

1. Борисевич В. Б. Технологические болезни сельскохозяйственных животных / В. Б. Борисе- продукти гнійного розпаду.

Висновок. Отже, спираючись на отримані дані, можна зробити висновок, що ми маємо справу 3 гострим генералізованим остеомієлітом, артритом копитцевого і вінцевого суглобів, ознаками параартикулярної флегмони. Для з'ясування етіології та диференційної діагностики необхідно провести мікробіологічні та гістологічні дослідження, результати яких будуть предметом наших наступних публікацій.

вич // Проблемы хирургической патологии с.-х. животных : тез. докл. Всесоюз. науч. конф. - Бе- 


\section{ВЕТЕРИНАРНА МЕДИЦИНА}

лая Церковь, 1991. - С. 58.

2. Бурденюк А. Ф. Заболевание копытец у крупного рогатого скота и свиней / А. Ф. Бурденюк. К. : Госсельхозиздат, 1959. - $186 \mathrm{c.}$

3. Дугин А. В. Комплексное лечение гнойнонекротических поражений тканей пальцев у свиней : автореф. дисс. на соиск. уч. степени к. вет. н. : спец. 16.00.05 «Ветеринарная хирургия» / А. В. Дугин. - Курск, 1999. - 19 с.

4. Елисеев А. Н. Травматизм свиней: профилактика, лечение / А. Н. Елисеев // Ветеринария. 2011. - №7. - С. 43-46.

5. Издепский В. И. Артриты у свиней: этиология, иммунология, клиника и патогенетические методы лечения : автореф. дисс. на соиск. уч. степени д. вет. н. : спец. 16.00 .05 «Ветеринарная хирургия» / В. И. Издепский. - К., 1993. - 39 с.
6. Кантемир О. В. Диференційна рентгенодіагностика хірургічної патології дистального відділу кінцівок великої рогатої худоби, ії профілактика і лікування : автореф. дис. на здобуття наук. ступ. к. вет. н. : спец. 16.00.05 «Ветеринарна хірургія» / О. В. Кантемир. - Харків, 1999. - 18 с.

7. Кузнеиов Г. С. Хирургические болезни животных в хозяйствах промышленного типа / Г. С. Кузнецов. - Л. : Колос, 1980. - 224 с.

8. Рубленко М. В. Патогенетичні особливості запальної реакції у свиней при хірургічних хворобах та методи їх лікування : автореф. дис. на здобуття наук. ступеня д. вет. н. : спец. 16.00.05 «Ветеринарна хірургія» / М. В. Рубленко. - Біла Церква, 2000. - 35 с. 